\title{
Setting up strategies: patient inclusion in biobank and genomics research in Europe
}

\author{
Pauline McCormack ${ }^{1 *}$, Anna Kole \\ From 7th European Conference on Rare Diseases and Orphan Products (ECRD 2014)
}

Rare disease patient organisations have a tendency to be deeply involved in research development and infrastructures, and are practiced at founding strategic alliances with clinical and research networks [1]. In building an integrated platform for rare disease databases, registries, biobanks and bioinformatics through the RD Connect project, we wanted to explore explicitly and in detail, the inclusion of rare disease patients and their advocates in RD Connect's core activities.

RD Connect collaborates closely with two related research projects EURenOmics (rare kidney disease) and Neuromics (rare neuromuscular/neurodegenerative disease) both of which utilise genomic technologies to improve care and therapies for specific disease groups. A workshop of 45 clinicians, scientists and patients/ advocates from RD Connect, EURenOmics and Neuromics, identified two areas of concern. The first were procedural, around the inclusion of patients in governance including: on-going dialogue between researchers and patients; mutual education; and reporting and dissemi nation. The second set were contemporary ethical, legal and social issues (ELSI), around privacy, informed consent, data sharing, return of results and incidental findings. A review of the literature found that rare disease patients' views on these contemporary issues are rarely documented.

To explore these two areas we have parallel initiatives designed to include patients through membership of boards and committees at the highest levels and via a specific research strand investigating ELSI. Through including patients in governance, RD Connect fulfils the top level of Arnstein's ladder of participation, that of citizen control, whereby those who the governance structure serves are represented in decision making [2]. Among other things,

\footnotetext{
* Correspondence: pauline.mccormack@ncl.ac.uk

'Policy, Ethics \& Life Sciences Research Centre (PEALS), Newcastle University, Newcastle upon Tyne, Tyne and Wear, NE1 7RU, UK

Full list of author information is available at the end of the article
}

a Patient Advisory Committee works to discuss and build consensus on issues affecting patients and a Patient and Ethics Council promotes dialogue on ELSI between patients/advocates and researchers within RD Connect, Neuromics and EURenOmics.

In our research strand we are exploring patient hopes, expectations, concerns and fears for the creation of an integrated platform for rare disease databases, registries and biobanks in a series of focus groups and a Delphi exercise. Using the notion of communities of practice, which encourage collective learning through shared endeavour, we aim to use the findings from this research to inform discussion and education activities which will enable patient perspectives to be embedded into the work of RD Connect, EURenOmics and Neuromics [3]. Bearing in mind that patient organisations and scientific groups may have different decision making mechanisms, we will experiment with creating spaces to allow meaningful, on-going dialogue between patients/ advocates and researchers [4].

\section{Acknowledgements}

This work has been supported by the European Union Seventh Framework Programme (FP7/2007-2013) under grant agreement 305444 (RD-Connect).

\section{Authors' details}

${ }^{1}$ Policy, Ethics \& Life Sciences Research Centre (PEALS), Newcastle University, Newcastle upon Tyne, Tyne and Wear, NE1 7RU, UK. 'EURORDIS Plateforme Maladies Rares, Paris, 75014, France.

Published: 11 November 2014

\section{References}

1. Woods S, McCormack P: Disputing the ethics of research: the challenge from bioethics and patient activism to the interpretation of the Declaration of Helsinki in clinical trials. Bioethics 2013, 27(5):243-250.

2. Arnstein, Sherry R: A Ladder of Citizen Participation. JAIP 1969, 35(4):216-224.

3. Lave J, Wenger E: Situated Learning: Legitimate Peripheral Participation. Cambridge: Cambridge University Press; 1991

4. Moreira T: The transformation of contemporary healthcare: the market, the laboratory and the forum. New York: Routledge/Taylor Francis; 2012.
() Biomed Central

(c) 2014 McCormack and Kole; licensee BioMed Central Ltd. This is an Open Access article distributed under the terms of the Creative Commons Attribution License (http://creativecommons.org/licenses/by/4.0), which permits unrestricted use, distribution, and reproduction in any medium, provided the original work is properly cited. The Creative Commons Public Domain Dedication waiver (http://creativecommons.org/publicdomain/zero/1.0/) applies to the data made available in this article, unless otherwise stated. 
doi:10.1186/1750-1172-9-S1-P2

Cite this article as: McCormack and Kole: Setting up strategies: patient inclusion in biobank and genomics research in Europe. Orphanet Journal of Rare Diseases 2014 9(Suppl 1):P2.

Submit your next manuscript to BioMed Central and take full advantage of:

- Convenient online submission

- Thorough peer review

- No space constraints or color figure charges

- Immediate publication on acceptance

- Inclusion in PubMed, CAS, Scopus and Google Scholar

- Research which is freely available for redistribution

Submit your manuscript at www.biomedcentral.com/submit 